\title{
The challenge of postmodernism to rationality in Practical Theology
}

\begin{abstract}
As with previous eras, the postmodern age presents great opportunity and grave peril for the church and to Practical Theology as an academic discipline. The article gives a meta-theoretical description and evaluation of the development of the theological rationality of Practical Theological paradigms. To enable the researcher to explore the challenge of postmodern paradigms, the article describes the rationality of the Newtonian epistemology, followed by a discussion of the ecosystemic and the communication actions approaches. Postmodernistic approaches are evaluated in view of the developments. The rationality of correlative approaches is described as a viable approach to the challenges of the postmodern culture. Two examples of South African researchers are discussed to illustrate the role of rationality in Practical Theology. It is proposed that a rationality of correlation poses a hermeneutical key to a practical theological paradigm.
\end{abstract}

\section{INTRODUCTION: THE CHALLENGE OF POSTMODERNISM/POSTMODERNITY}

The article focuses on the challenge of postmodernism, a concept, which can be, interpreted as futuristic - or at least evolving - to practical theology. In his article on "Theology in a postmodern culture: ten challenges" GJ Rossouw (1993) a philosopher discussed some dimensions of the cultural shift from modernism to post modernism and the challenges and opportunities it offers to theologians. He specifically refers to four dimensions of postmodern culture, which invites theologians to a conversation. He mentions a broader rationality, a broader anthropology, expertise and experience and global village. In his discussion he mentions at least four challenges of Postmodernism for theology. And these are critical self-reflection, involvement in moral discourses, a spirituality of wholeness and narrative theology. He specifically focused on the rejection by modernity of discourses on values, ultimate ends and meaning of life. He said: "The dilemma that surfaced is the rejection by a modernist rationality of the importance of values, ultimate ends and meaning of life. It has become evident that a revision of modernist rationality is inevitable, a broader rationality that will include the so called non-rational and non -mechanical dimensions of life is needed." (Rossouw, 1993:897). This poses opportunities.

In line with Rossouw's argument Stanley Grentz, professor of theology and ethics at Regent College in Vancouver, British Columbia calls for a rebirth of theological reflection, a shift from a solely propositional paradigm (S Grentz in R A Mohler, 1995:78):

Evangelical theologians ought to move away from conceiving their task as merely to discover divinely disclosed truth understood as the single, unified doctrinal system (objective) lodged within the pages of the Bible and waiting to be categorized and systematized. Evangelical theologians should not focus intently upon doctrine and issues of prepositional truth but upon spiritual vision of the community. Theology must conduct a conversation with the other disciplines and this must cohere with human (subjective) 
experience. It is clear that evangelical theology does present a variety of views on salvation based on different views on the subject - object polarity.

This view is shared by Carl Raschke who writes, "During the past several decades, while postmodernism has altered the face of academic culture, particularly in the arts and humanities, it has only recently begun to pound at the door of evangelical thought and faith" (Raschke, 2004:11). Dreyer (1994:5) interprets the challenge as an "exciting risk". This view is shared by Mohler: "The challenge may be viewed as an opportunity to transcend the corrosive elements of the older modern ideologies and the restatement of Christian truths in terms faithful to the biblical revelation and the Christian tradition and yet addressed to a new consciousness" (R A Mohler in Dockery, 1995: 84).

The challenge is however interpreted not only as an opportunity but also as a threat. Johan Janse van Rensburg (2000: 55), a South African theologian with a confessional approach to Practical Theology, speaks of postmodernism as an "onslaught" or an "attack on the basic principles of the Christian faith". He explains: "the objective truth of God's being is no longer the point of departure for theology. People's experience of God, the narratives about God, the subject and the community constitute the postmodern theology. Static, systematic concepts of God are traded for dynamic concepts, creating a hermeneutic and communicative crisis". He quotes Gergen (1992) who says, "Once post modernistic views are savoured they can scarcely be abandoned. Once tasted the appetite becomes insatiable sweet poison."

\section{RESEARCH METHODOLOGY}

Two questions guide this article -

What are the challenges and opportunities posed to Practical Theology in South Africa?

How has Practical Theology in South Africa reacted to the challenge and opportunities posed by post Modernism?

How has the church reacted to the challenge?

The last question will be addressed in a second article on the Challenge of postmodernity for church ministry.

\subsection{Key terms}

To address the posed research questions the conceptualisation of key terms is addressed.

Since the publication of J-P Lyotard's text: The postmodern condition in 1984, many disciplines have been challenged by a new paradigm. The concept, postmodern, was not entered in the Dictionary of pastoral care and counselling published in 1990 but has since been included - an indication of the relevance of the concept for the field of pastoral care. Since the publication of J-P Lyotard's text: The postmodern condition in 1984, many disciplines have been challenged by the new paradigm. Working in the discipline of pastoral counselling, J Patton wrote an article "Pastoral postmodernism" in1994 and in 1995, a conference of pastoral organisations in Germany focused on the theme "Pastoral care and counselling in postmodern times" (Lyall 2001:60)

Pamela Couture wrote an article entitled "The effect of the postmodern on pastoral/practical theology and care and counselling". She distinguished between postmodernity (social context/ culture) and postmodernism (cultural philosophy) in an attempt to clarify confusion between the concepts. She defines postmodernity as a cultural state: "It defines changes in global culture associated with the decline of meta-narratives, respect for human differences, the fragmentation of communal life, loss of confidence in scientific reason, the rise of technology and virtual reality, the re-emergence of an integrated global economy and the development of a post-colonial identity" (Couture 2003:85). This conceptualisation is in line with Rossouw, (1993:895) a South 
African philosopher, who discussed the challenge, which the postmodern culture poses for theology. One excellent example of the conceptualisation of this concept in the South African context is the work by N Niemandt, a missiologist. He published a book addressing the "dreams" or opportunities of postmodernism for communities of faith. He describes postmodernism as a big storm, which is a threat to faith communities, especially those communities that function in line with a modernistic paradigm. He describes the concepts of the emerging church as an answer to the threat. Writing as a reformed pastor, he says, "The speed, diversity and complexity of social and cultural changes in western industrialized settings have particularly taxed reformed theology with its particular openness to contemporary cultural developments" (Niemandt 2007:47).

In a positive optimistic mode he says, "God himself is stirring the pot. If we can pay attention we will eventually discover that not only will we lose God in this emerging postmodern world, we will find him again" (Niemandt 2007:49).

Couture (2003) defines the other concept, postmodernism, as a school of thought (a philosophy), which analyses and defines the metatheoretical philosophical reflection about postmodernity.

P M Rosenau (1992:15-16) in her work, Postmodernism and the social sciences, distinguishes between affirmative and sceptical postmodernism. Of affirmative postmodernism she says, "It is a more hopeful, optimistic view. They do not shy away from affirming an ethic and making normative choices". Of sceptical postmodernism she speaks of "fragmentation, disintegration, malaise, meaninglessness, a vagueness or even absence of moral parameters and societal chaos. There is no truth, all that is left is play, the play of words and meaning."

Evangelical Theology is defined in this research as the contemporary representation of the evangelical movement. A König (1998: 96) refers to Packer who describes evangelical theology as "the doctrine of God's free and sovereign grace to sinners that is again and again expressed in opposition to what is false as Paul spoke against the Judaizers, Augustine against Pelagius, Luther against Erasmus, Calvin against the Scholastics". He lists four key features: "The Bible is God's instruction, God is in a Trinitarian shape, human nature is seen in a radical view of sin and grace and the deepest truth about the church is that it is invisible and an object of faith."

Practical Theology is defined as an interpretative discipline, which involves four key tasks: "the descriptive-empirical task, the interpretive task, the normative task and the pragmatic task. These four tasks interpenetrate" (R.R. Osmer, 2008:10). The normative and descriptive tasks are central to Practical Theology as a discipline is.

\subsection{Research approach}

\subsubsection{Problem statement}

Practical theology as a discipline has established itself as part of the universitas scientiarium (Pieterse, 1993:40). This stance challenged Practical Theology to formulate answers about the approach to science and methodology. This challenge includes the formulation and clarity on rationality. Rossouw (1993:895) says for Theology to understand modernity and the challenge of postmodernism a focus on the rationality is a good starting point. He formulates rationality as the standard that a society requires for making intelligible and meaningful statement about reality. Osmer $(2008,114)$, a scholar from Princeton, says a model of rationality, which includes argumentation, perspectivalism and fallibility, opens up forms of analysis and evaluation of theories. To engage in the discussion of the challenge of culture (e.g. Postmodernism) for a discipline like Practical Theology clarity on the rationality of the theories of Practical Theology need to be determined .In this article two problems will be addressed- 


\subsubsection{Primary research problem}

What is the challenge (interpreted as both a threat and an opportunity) of postmodernism to practical theology? This problem entails the analysis and evaluation of the theories or metatheory of practical theology .It also entails the focus on the inherent cross - disciplinary nature of practical theology .How can the constructive theological perspective of practical theology dialogue with other disciplines?

\subsubsection{Secondary research problem}

What are the outcomes of the response of practical theology to the challenge?

\subsection{Methodology}

To enable the researcher to address the problem as stated, a methodology of conceptual analysis of the meaning of words or concepts through clarification and elaboration of different dimensions of meaning is chosen. Conceptual clarity is aspired to by a normative evaluation of meta-theoretical approaches (Mouton 2001:175).

\section{AN OVERVIEW OF THE INTERPRETATION OF RATIONALITY IN PRACTICAL THEOLOGICAL}

\subsection{A theological interpretation of rationality}

The chosen point of departure to formulate an understanding of the challenge of postmodernism to practical theology is an interpretation of Newtonian rationality.

\subsubsection{The rationality of ecosystems}

The elected point of departure in this article is to consider critically the shift in rationality from a Newtonian (modernist) epistemology to ecosystemic epistemologies. The difference in basic concepts relating to social sciences is illustrated in a figure developed by D P Fourie (1998:8) writing from a psychological perspective.

\begin{tabular}{|c|c|c|}
\hline \multirow[t]{2}{*}{ Level } & \multicolumn{2}{|l|}{ Approach } \\
\hline & Newtonian & Ecosystemic \\
\hline Epistemology & $\begin{array}{l}\text { Objectivity: the "real" nature of } \\
\text { things }\end{array}$ & $\begin{array}{l}\text { Constructivism } \\
\text { Relativity }\end{array}$ \\
\hline Paradigm & $\begin{array}{l}\text { Reductionism } \\
\text { Causality }\end{array}$ & $\begin{array}{l}\text { Holism } \\
\text { Fit }\end{array}$ \\
\hline Theory & Mechanistic & Cybernetic \\
\hline Research & $\begin{array}{l}\text { Proving } \\
\text { Validating }\end{array}$ & $\begin{array}{l}\text { Making sense } \\
\text { Describing }\end{array}$ \\
\hline Methodology & Objective & Consensual \\
\hline Results & Proof & Guidelines \\
\hline Application & Mechanical & Creative \\
\hline Hypnosis & $\begin{array}{l}\text { Individual } \\
\text { Intrapsychic }\end{array}$ & Contextual \\
\hline
\end{tabular}

Fourie (1998:8) explains the modernistic rationality known as the Newtonian epistemology as follows:

The philosophical basis of modernism with reference to philosophers such as Aristotle, 
Descartes and Newton rests on three assumptions:

a. Reductionism or atomism

To understand a phenomenon or object it needs to be reduced to its most basic elements, which are easier to understand.

b. Linear causality

Elements or most basic elements are regarded as being connected to one another through cause and effect.

\section{c. Neutral objectivity}

One can only know what an object or phenomenon is really like if one does not influence it.

The cultural era of modernity is often equated with the late seventeenth to eighteenth century Age of Enlightment (Goodliff, 1998, 28). The heroes of the Enlightment were Rene Descartes, John Locke and Immanuel Kant. Against the backdrop of the Thirty Years War (1618-1648) a complex series of struggles originating in religious conflicts between Protestants and Catholics which embraced wider political factors. In reaction to the failure of religion, thinkers looked for a new foundation of knowledge and progress in the power of human rationality. A concept was epitomised by Descartes' statement -“I think therefore I am". Upon this foundation of reason a utopia of prosperous and fulfilling society was build. The future was scientific, technological and economic. Immanuel Kant distinguished between theoretical rationality and practical rationality. Whereas the theoretical refers to the Newtonian notion of the res cogitans (thinking substance) practical rationality refers to the moral and metaphysical aspects of man.

Fourie (1998:13) mentions how more and more fields of scientific enquiry have encountered problems of increasing complexity, which lead to the exposure of the inadequacies of a Newtonian rationality.

Criticism of the Newtonian epistemology of science came from the natural sciences, biology, anthropology, psychology and family therapy.

General systems theory and second-order cybernetics posed a new philosophical basis for rationality. Not only was the shift from a Newtonian paradigm to an ecosystemic paradigm relevant for social sciences but it also impacted on Practical Theology.

J Muller (1991) used the concept of eco-hermeneutical which is a combination of two terms ecosystemic and hermeneutical where the first refers to the widest network of systems and the second emphasises the element of understanding. The hermeneutical circle implies that in all interpretation there is a reciprocal relationship between the parts and the whole.

JT De Jong van Arkel (1991: 61) describes the implications of systems theory as a metatheory for Practical Theology. He says: "Naas die kommunikatiewe handelingsteorie word die sisteemteorie ook op meta-teoretiese vlak aanvaar en bied sodoende 'n brug met ander wetenskappe" (De Jong Van Arkel 1991:61).

He proposes an ecosystemic theory as a metatheory for Practical Theology as a corrective to the General Systems Theory (GST). He mentions that the GST could still accommodate the mechanistic and reductionistic rationality of the Newtonian epistemology of objectivity with the split of the subject and object - a notion identified in Newtonianism.

\subsubsection{The broader rationality of actions theory}

Another development in the rationality of Practical Theology was the development of actions theory as metatheory. In the 1990s HJC Pieterse claimed that Practical Theology was formulating its scientific rationality. Pieterse (1991: 1 ) discussed the implications of the role of the communicative actions theory as a bridge from practical theology to other sciences. The development of communication actions theory in Practical Theology was a development from a 
narrowed rationality to a broader rationality.

When Pieterse discusses the scientific basis for Practical Theology (Pieterse 1992 in "Wetenskapsteoretiese grondslag van die Praktiese Teologie"), he describes the development of a broader hermeneutical based rationality. This was a development from the objective approach of the natural sciences to a hermeneutical approach. This rationality incorporates both irrational aspects like intentions as well as normative and subjective aspects. The social reality is epistemologically approached from the perspective of meaning - even subjective meaning - not from the perspective of objectivity in which reality is stripped of intentions, acts and social factors and meaning. Pieterse (1991) specifically refers to J Habermas who criticised critical rationalism for its narrowed rationality. Habermas used the concept of "erkenntnisleitende Interesse" by which he meant that there is a predetermined interactive relationship between the object and subject, between theory and practice. In his book, Theorie des Kommunikativen Handelns (1982), Habermas worked with the concept of communicative actions. The rationality of his approach is based on three domains of reality: the objective reality of facts, the subjective reality of intentions, needs and emotions, and the social reality of norms and values. In this approach, validity is reached by means of intersubjective consensus. It was specifically Rolf Zerfass (1974) in his article, "Praktische Theologie als Handlungswissenschaft", who based his approach to Practical Theology on the theory of Habermas. Pieterse (1993) explains that this actions theory was refined into a communications action theory applicable to Practical Theology.

In his discussion of an ecosystemic paradigm, De Jong van Arkel proposes a shift from a paradigm of actions (which is the case with the communications action paradigm) to a system of semantic meanings (intersubjective linguistic realties). This was a shift towards constructivist rationality.

\subsubsection{The rationality of postmodern paradigms}

In Practical Theology the limited rationality of Newtonian epistemology was challenged not only by the ecosystems approach and the actions theory but also by a postmodernistic paradigm based on social constructivism. Rossouw (1993) described the development from a medieval society where rationality was based on the distinction between the transcendent and the immanent. The emphasis was on the transcendent. Every dimension of society was subordinate to the divine plan - as the church presented it. The modern culture, which replaced medieval culture, rejected the basic rationality of the distinction between transcendent and immanent and replaced it with the more superior distinction between object and subject . The subject was defined as the independent rational thinking subject. This rationality however delegitimizes a discourse on values and ultimate ends and on meaning. Faced with this a dilemma a revision of the modernist rationality was evident.

A broader rationality J C Muller (2008:4-5) as a shift from foundationalism (universal perspective) to post-focussing only on the structure of the self, ego or subject foundationalism (transversal) distinguished from non-foundationalist or multiversal perspective.

He refers to J W van Huyssteen's (2006) exposition of multiversality to substantiate his notion of interdisciplinary dialogue. He quotes Van Huyssteen (Muller 2008:7): “A postfoundationalist approach helps us realize ... that we are not the intellectual prisoners of our contexts or traditions, but that we are epistemologically empowered to cross contextual, cultural and disciplinary borders to explore critically the theories, meanings and beliefs through which we and others construct our worlds."

He formulates the shift from individual subjectivity: "The shift of emphasis from individual to social, from subjective to discourse, which constitutes a new epistemology in the social sciences, is also part and parcel of the postfoundationalist movement." Van Huyssteen formulates the shift 
as follows: "Talk about the human subject is now revisioned by resituating the human subject in the space of communicative praxis. Thus the notion of transversal rationality opens up the possibility to focus on patterns of discourse and action rather than focusing only on the structure of the self, ego or subject."

The point that was raised in the discussion of systems theory was that the systems paradigm still accommodated the subject, interpreted as the individual (see De Jong van Arkel) but this view need to be revised.

A new formulation of the rationality of the subject was formulated by Rosenau (1992). She argues for the return of a focus on the individual "subject" in her discussion of the different views of postmodernists. She formulates two different postmodernistic views on the subject. Sceptical subjectivity opposes the modernist notion of the subject/individual for three reasons: because it is an invention of modernity, because it assumes a humanist philosophy and because the subject automatically requires an object (Rosenau 1992:46).

She provides an argument that the research by postmodernists based on subjectlessness varies from discipline to discipline. She suggests that there are indications that the death penalty for the subject as a personally disciplined and responsible personality was too extreme a punishment. If there has been a period of temporary death of the subject then that interval is coming to an end and support for a radically more lenient attitude is on the rise (Rosenau 1992: 57). It is clear that at least in sociology and anthropology there is a tendency for the "subject" to return, fully developed (Rosenau 1992:51).

When she discusses the views of the affirmative postmodernists, she calls it a proposal for the return of the subject but in new and novel forms, which avoids those aspects of the modernist subject that were found to be most objectionable. Her views need to be utilised to interpret the intersubjectivity of the post and antifoundationalist views of rationality in Practical Theology.

Osmer in his book Practical Theology: An introduction points out that the concept of transversality appeared simultaneously in a number of fields. He says (2008: 170):

"In these disciplines and others, transversality means 'Iying across, extending over, intersecting, meeting and converging without achieving coincidence'. In comparison to the other models of dialogue between disciplines, this model presupposes a more fluid and dynamic understanding of the relationship between disciplines. A meta-theoretical view of modernism focused on the rational notion of objective certainty and the splitting of the object and subject. A Post modernistic epistemology focuses on the correlation of subject and object in the self and on interdisciplinary consensus in the search for scientific certainty."

The question to be discussed is what is the significance of the notion of correlation between the subject and the object and of interdisciplinary consensus for Practical Theology.

\subsubsection{The rationality of correlational approaches}

Osmer (2008), in his discussion of the normative task of Practical Theology, gives an overview of models of cross-disciplinary dialogue between practical theology and other disciplines. He comments, "In contemporary theology three models have emerged to picture the dialogue between theology and other fields; correlational, transformational and transversal"(Osmer 2008:164). He differentiates between the transversal, transformational and correlational models.

He explains the rationality of correlational models: "When used as a model of dialogue, the quantitative dimension of scientific correlation drops away (negative analogy). What is emphasized is the way a genuine dialogue is a conversation in which the parties enter into a 
mutually influential relationship (positive analogy)." This correlation can be viewed as a matter of tension from different viewpoints. De Koker (1998: 454), a South African theologian, believes that "the constants at play in the total hermeneutical process are those of transcendence and immanence, subject and object. A critical perspective brings to light that there appears to be a constant tension between opposite poles. Not only is there a constant switch between the subjective and the objective poles in the quest for understanding of the Bible but also in different spiritualities."

The rationality of the concept of correlation finds a theological basis in the construct of analogy which is discussed in systematic theology on the anthropological notion of man as created in the image of God. (Heitink, 1977, 113). Heitink says it addresses the difficult hermeneutical challenge posed by the question about the similarity or difference between Biblical and empirical articulations about man. The relevance of the construct of analogy for pastoral theology was addressed in his monumental work Pastoraat als Hulpverlening: Inleiding in de pastorale theologie en psychologie and in his newer work, Pastorale Zorg: Theologie, differentiatie, praktijk (1998). He formulated the concept of bipolarity as a hermeneutical key to formulate the complementarity of different concepts including the subject-object rationality. He says, "God blijft God en de mens wordt mens. Leer en leven, fides quae en fides qua creditor, object en subject, heilsgescheidenis en levensgeschiedenis, openbaring en menselijke ervaring, communicatie 'van' en 'tussen' zijn zo op elkaar betrokken dat steeds alleen via het ene moment het andere tot zijn recht kan komen." He made it clear that he wants to formulate the complementarity (evenwicht) between the godly and the human factors. He based his views on the systematic views of $\mathrm{H}$ Berkhof (1973), which are based on a complementarity of the godly and human - "het ene wordt pas zichzelf door het andere", "the one only becomes true to himself by means of the other." Berkhof based his view on a trend that becomes more and more relevant in theories, which focus on life as a process and on life's development by leaps and bounds. In his comments on the concept of bipolarity in Pastoral Theology, D J Louw (1984: 22-23) refers to different approaches, including Berkhof's approach, which formulates the Godman relationship. He refers to $\mathrm{P}$ Tillich (analogia entis - this concept described the spirit of man analogous to God's spirit), K Barth (analogia fidei - this concept describes the spirit of God analogous to the spirit of man), $\mathrm{H}$ Berkhof (complementarity), Van Ruler (reciprocity) and Berkouwer (correlation of faith). Louw believes Heitink is in line with $\mathrm{F}$ Wintzer who speaks of bipolarity between different aspects of pastoral work: "Bezeugen und Beraten", "geloofshulp en lewenshulp". Louw however maintains that the bipolarity seen as complementarity has the implication that God is explained by man and vice versa. He formulates, with a focus on eschatology, a teleological approach in which the bipolarity between God and man is not seen as a complementarity to not neglect the difference. Teleology is based on an eschatology of "belofte-in-vervulling" and not on communication. Eschatology interprets complementarity as a God-given gift.

The bipolarity imposed by the radical Cartesian subject-object split for theology and spirituality becomes clear from a presentation by PF Theron (1990) of the systematic theological problem formulated as "What is the relationship between the objective involvement of God to save man and the subjective realm of faith and conversion by man."

He formulates the problem as a dualistic polarity originating from Greek philosophy and accentuated by Descartes. This view leads to three possible formulations:

\section{Polarity}

a. Human beings have a personal autonomy in relation to God. Humans are responsible for their own destiny and are themselves capable of saving themselves by faith and conversion. God is 
only responsible for 50 percent of human beings' destiny.

b. The total opposite of a. Humans are saved by means of an objective - extra nos intervention by God. Humans can only rationally take notice of God's objective work.

\section{A-polarity}

c. God-and-humans-in-relation. This view states that humankind and God are not concurrently related but they are covenantal related. Human beings owe their existence to God: without God there is no existence.

This a-polarity (see Leviticus 20:7-8, Philippians 2: 12-13) is an indication that humankind and God are seen as qualitatively different entities contrary to a bipolar perspective where God and humankind are seen as qualitatively on the same level (niveau).

He (Theron 1990:8-9) formulates it as follows:

"Die fout met die polêre denke bestaan daarin dat God en mens op dieselfde vlak (niveau)

gedink word. Die verskil tussen God en mens is dan slegs kwantitatief in plaas van

kwalitatief. Volgens die Skrif is God en mens nie konkurrent nie maar bondgenote. Die mens beskik nie oor ' $n$ eie bestaan wat dan ook nog in ' $n$ relasie tot God bestaan nie maar die mens bestaan kragtens sy verhouding met God."

This view is a confirmation of the explanation by WD Jonker (1981) of the Reformed stance on righteousness and sanctification. He refers to GC Berkouwer who describes the God-Man relationship as a covenant. Jonker (1981: 200) says: "Dit is duidelik dat die wyse waarop Berkouwer die begrip korrelasie hanteer en hom verset teen elke vorm van polêre denke, van sy teologie 'n voorbeeld van verbondsmatige denke maak" He formulates three options to explain different views:

- The polarity between God and humankind. God is merciful but He is bounded by man's responsibility.

- God works alone and humankind is passively involved.

- There is a correlation between God and humankind (Jonker1981: 192).

The implications of this principle for a practical theological rationality suggest a corrective to a correlation based on bipolarity.

\section{THE ROLE OF RATIONALITY IN DIFFERENT APPROACHES TO PRACTICAL THEOLOGY}

The research into the implications of rationality for the discipline of Practical theology presents two examples.

\subsection{A diaconological approach}

J Janse van Rensburg (2000: 92) discussed the implications of postmodern thought for Practical Theology in his book, Paradigm shift: An introduction to postmodern thought and its implications for theology.

He proposes an inter-subjective hermeneutic approach without minimising the importance of the particular contexts or without compromising ethical principles. In his approach he rejects what he calls the ethical "relativism of postmodernity". He is of the opinion that postmodern epistemologies and Christian ethical norms are incompatible. His approach is based on a subjectobject split. On page 97 of his book he refers to postmodernism as an onslaught, an "attack on the most basic principles of the Christian faith". In this view the "objective truth of God's being is no longer the point of departure for theology in Postmodernism. People's experiences of 
God, the subjective and the community constitute the postmodern theology. Static, systematic concepts of God are traded for dynamic, concepts, creating a hermeneutic and communicative crisis." He refers to P Ricoeur's constructivist hermeneutics and concludes that it opens the door to a postmodern frame of mind. For Janse van Rensburg, Ricoeur presents a return to a subjective sensitivity and a loss of objectivity. Even though Van Rensburg warns that Ricoeur's approach does not suggest subjectivism, he says, "It does imply that the final choice rests with the ' $\mathrm{l}$ ' to construct his or her reality from the task".

In reaction to the subjective sensitivity of Ricoeur, Janse van Rensburg proposes a subjectivesubjective approach. In the work of the pastor this means that "it is the ideal of the Christian to come as close as possible to the perfect example of Christ, this goal should be pursued, even though the pastor may realise the person may not accept such scriptural directives". Although he proposes an inter-subjective approach he advocates a diaconological (biblical) model, which defines a directive strategy.

It is clear that he promotes Practical Theology as diaconology based on an epistemology, which acknowledges the objective truth of the Bible. In his view postmodern hermeneutics must be viewed as "sweet poison". He quotes K J Gergen (1992) who says, "Once post modernistic views are savoured they can scarcely be abandoned. Once tasted the appetite becomes insatiable."

\subsection{A postfoundationalist approach}

Another approach to Practical Theology is based on the notion of transversal rationality (J Muller 2008: 4). Muller quotes C O Schrag (1992) who says, "From radical hermeneutics we learn that there is no truth at the bottom of being, no final, bedrock, correct interpretation that supplies the 'letzte begrundung'. On the other hand, the hurried and facile claim of relativism that every interpretation is as good as every other is equally misguided."

He then typifies his approach as "always concrete, local and contextual but at the same time reaches beyond local contexts to transdisciplinary concerns". He also quotes JW van Huyssteen (2006) who says, "Talk about the human subject is now revisioned by resituating the human subject in the space of communicative praxis." Practical theology from the transversal approach focuses on social contexts and on embeddedness rather than on abstract beliefs. The locus of rationality is embodied persons. The implications are that the normative interpretative emphasis in Practical Theology described by RR Osmer (2008), is replaced by interconnectedness and communicative practices. The postfoundationalist approach can be identified as being in line with affirmative postmodernism (PM Rosenau), which focuses on an optimistic view and on the making of normative choices.

\section{CONCLUSION}

The challenge of postmodernism to rationality in Practical Theology leads to a focus on and a reconsideration of the rationality of Practical Theological approaches. It seems that the development from a limited rationality of the Newtonian philosophy to a broadened rationality of the communications actions approach has been accommodated in a wider approach in postmodernistic rationality. Rossouw (1993) described two opposing reactions of theology to modern rationality. The first was total rejection, which lead to the total irrelevance of theology for the modern world. Another reaction was the "if-you-can't-beat-them-join-them-approach". This resulted in a rationalistic and logical theological exercise, which was timeless and irrelevant for the culture. It is suggested that the correlative approach be reformulated in the conceptualisation of rationality in Practical theology to address the challenges of a postmodern culture. Osmer (2008:163) says - 'it is not too much to say that practical theology as an academic field are 
inherently cross-disciplinary in nature. This means that Practical Theology brings theology into dialogue with other theological disciplines and the arts and science. A rationality that enables the discipline to participate in a dialogue can be developed from a correlational approach.

\section{BIBLIOGRAPHY}

Berkhof, H. 1973. Christelijk geloof: Een inleiding tot de geloofsleer. Nijkerk.

Couture, P.D. 2003.The effect of the postmodern on pastoral/practical theology

and care and counselling. The Journal of Pastoral Theology, 13 (1): 85-106.

De Jong van Arkel, J.T.1991. Ekosisteem denke as meta-teorie in die Praktiese Teologie. Praktiese Teologie in Suid-Afrika, 6(1):61-75.

De Koker, W .1998 Evangelisasieteorie en -Praktyk in die lig van die paradigmaverskuiwing van mOdernisme na Postmodernisme

Practical Theology in South Africa, 13(1):1-13

Dockery, D.S. 1995. The challenge of postmodernism. An evangelical engagement.Louisville Kentucky: Bridgepoint.

Dreyer,T.F.J.1994 . Postmoderniteit: 'n Opwindende risiko. Die Hervormer, 5 Maart.

Dreyer, J.S. 1998. The Researcher and the researched: Methodological challenges for practical theology. Practical Theology in South Africa, 13(1):14-27.

Fourie, D.P. 1998..Hypnosis in treatment: An ecosystemic approach.

Pretoria: University of South Africa.

Gergen. K.J. 1992. Towards a postmodern psychology. In Kvale, S. Psychology and postmodernism. London: Sage:17-28.

Goodliff,P.1998.Care in a Confused Climate London: Darton, Longman \&Todd Ltd.

Grentz, S J 1994 Theology for the Community of God Nashville: Broadman and Holman

Grundy, S.1987. Curriculum: Product or praxis. Philadelphia, PA. Farmer.

Habermas, J. 1982, Theorie des Kommunikativen Handelns. Suhrkamp:Bd1711 Frankfurt .

Heitink, G.1977. Pastoraat als Hulpverlening: Inleiding in de pastorale theologie en psychologie. Kampen: Uitgeverij Kok.

Heitink, G. 1998. Pastorale zorg: Theologie - differentiatie-praktijk. Kampen: Uitgeverij Kok.

Heyns, L.M. \& Pieterse H.J.C. 1990. A primer in practical theology. Pretoria: Gnosis.

Hunter, R.J. 1990a. Dictionary of pastoral care and counselling ..NashvilleTN:Abingdon Press .

Janse van Rensburg, J. 2000. Paradigm shift: An introduction to postmodern

thought and its implications for theology. Pretoria: Van Schaik.

Jonker, W.D.1981. Uit vrye guns alleen: Wegwysers in die dogmatiek.

Goodwood: NGKB.

König, A. \& Maimela, S. 1998. Initiation into theology: The rich variety of theology and hermeneutics. Pretoria: Van Schaik.

Louw, D.J .1984. Pastoraat in eskatalogiese perspektief. Kaapstad: Nederduitse Gereformeerde Kerkuitgewers.

Louw, D.J. 1998. Die konsep "prakties teologiese spiritualiteit" binne 'n konteks van postmodernisme en globalisering. Praktiese Teologie in Suid-Afrika,13 (2):16-25.

Lyall, D. 2001. The integrity of pastoral care. London: SPCK.

Lyotard, J-P. 1984. The postmodern condition. Translation G Bennington \&B Massumi in Theory and History of Literature Vol 10 Minneapolis: University of Minnesota Press .

Mohler, R.A.1995.The integrity of the Evangelical Tradition and the Challenge of the Postmodern Paradigm .In D.S. Dockery, (ed). The challenge of postmodernism. An evangelical engagement. Louisville Kentucky. A Bridgepoint Book.

Muller, J .C. 1991a Eko -hermeneutiese pastoraat en gemeenskapsonrtwikkeling: 'n Afrikaperspektief . Acta Theologia 2 91-98.

Muller, J.C. 2008. Postfoundationalism as a practical way of interdisciplinary dialogue: Narrative research in HIV and AIDS. Faculty of Theology: University of Pretoria.

Mouton, J. 2001. How to succeed in your masters and doctoral studies. A South African guide and resource 
book. Pretoria: Van Schaik.

Niemandt, N. 2007. Nuwe drome vir nuwe werklikhede. Geloofsgemeenskappe in pas met 'n postmoderne wereld. Epping: Lux Verbi.

Osmer, R.R. 2008. Practical theology: An introduction. Michigan: Grand Rapids, MI: Eerdmans.

Pieterse, H.J.C. 1991. Praktiese teologie as teologies wetenskap binne die teologiese fakulteit. Praktiese Teologie in Suid-Afrika, 6(2)): 249-254.

Pieterse, H.J.C 1995 . Die Wetenskapsteoreties grondslag van die Praktiese Teologie (Presentation at Society for Practiacl Thelogy)

Raschke, C. 2004. The next reformation: Why evangelicals must embrace postmodernity. Michigan: Blake Academic.

Rosenau, P.M.1992. Post-modernism and the social sciences. Princeton: Princeton University Press.

Rossouw, G.J. 1993. Theology in a postmodern culture: Ten challenges.

Hervormde Teologiese Studies, 49(4):894-907.

Schrag, C.O. 1992. The resources of rationality: A response to the postmodern challenge. Bloomington, Ind: Jonathan Ball.

Theron, P.F. 1990. Polêre en apolêre denke. Fakulteit Teologie, Universiteit van Stellenbosch, Stellenbosch.

Van Huyssteen, J.W. 2006. Alone in the world? Human uniqueness in science and theology. The Gifford Lectures. Grand Rapids, MI: Eerdmans.

Wittmer, M.E. 2008. Don't stop believing: Why living like Jesus is not enough.

Zondervan: Grand Rapids, MI.

Zerfass, R. 1988. Gottesdiens als Handlungsfeld der Kirche. Liturgisches Jahrbuch 38 (Heft1/2):30-59. 